\author{
K.S. Meiramkulova ${ }^{1}$, M.O. Ryspekova ${ }^{2}$, Sh.U.Niyazbekova ${ }^{3,},{ }^{*}$ A.A. Duisenbekova ${ }^{4}$ \\ ${ }^{1,2,4}$ L.N.Gumilyov Eurasian National University, Kazakhstan \\ ${ }^{3}$ Witte Moscow University, Russia \\ ${ }^{1}$ kuleke@gmail.com, ${ }^{2}$ Madina10081957@mail.ru, \\ 3shakizada.niyazbekova@gmail.com,4aigerim.duisenbekova95@gmail.com \\ ${ }^{1}$ https://orcid.org/0000-0002-0566-6472, ${ }^{2}$ https://orcid.org/0000-0001-5964-0342, \\ ${ }^{1 / 3}$ https://orcid.org/0000-0002-3433-9841, ${ }^{4}$ https://orcid.org/0000-0001-9167-8076
}

\title{
Analysis of the current state of production activity of the "Izhevsky" production cooperative of Akmola region
}

\begin{abstract}
Object: One of the most dynamically developing industries in the modern system of the agro-industrial complex of Kazakhstan is poultry farming. Today, it is crucial to stimulate the efficient production of high-quality poultry products. The article provides an economic overview of the production activities of the production cooperative "Izhevsk" of Akmola region, qualitatively and quantitatively considers the current state of production at this enterprise.

Methods: The following methods of research used during the work: methods of systemic, logical and comparative analysis, statistical methods. The information and empirical basis of the study were the data of the Committee on Statistics of the Ministry of National Economy of the Republic of Kazakhstan, the Department of Agriculture of the Akmola region, statistical reports of the Izhevsk production cooperative, as well as reference and regulatory materials, scientific and methodological recommendations, economic periodicals, and the information potential of the Internet.

Findings: The current state of the poultry industry of Akmola region briefly reviewed, the leading economic indicators of production activity of Izhevsk production cooperative were analyzed. It should be noted that the proposals made by the authors can be used by agricultural producers, district and regional agricultural departments.

Conclusions: The main conclusions drawn from the calculations can be used in the development of strategic plans for the development of poultry farming in the region.
\end{abstract}

Keywords: agriculture, poultry, animal husbandry, laying chickens, poultry, feeding, combined feed, poultry productivity.

\section{Introduction}

Within the framework of the agro-industrial sophisticated development program in the Republic of Kazakhstan "Agrobusiness 2020" for 2013-2020, the State Program for the development of the agroindustrial complex of the Republic of Kazakhstan for 2017-2021 and the producers of products are tasked with producing high-quality agricultural products with minimal damage to the ecology and environment . The development of poultry farming as one of the strategic sectors of animal husbandry in Kazakhstan is of great importance (Agro-industrial complex development program in the Republic of Kazakhstan for 20132020 "Agribusiness-2020).

Poultry farming is the most dynamic and knowledge-intensive industry in the world and domestic agroindustrial complex (State programme for the development of the agro-industrial complex of the Republic of Kazakhstan for 2017-2021).

In the world structure of meat of all types of animals, poultry occupies a WTO place after pork. According to the UN FAO, the annual increase in meat in 2011-2025 will be: for poultry $-3.1 \%$, pork - 2.6, beef 1.3 , and other animal species $-0.2 \%$. The leading countries in poultry meat production are the United States, China, Brazil and Russia.

Egg of hens contains all nutrients and biologically active substances necessary for humans, which are in optimal ratio: $12-15 \%$ protein, $11-15 \%$ fat, $1 \%$ carbohydrates, $74 \%$ water, and about $1 \%$ inorganic substances. The biological value of poultry egg proteins is due to the set and ratio of essential amino acids absorbed by humans by $96-98 \%$. The egg contains more than 20 minerals, vitamins, and essential amino acid - lysozyme. The nutritional value of a chicken egg is about 75 calories (Ahearn, M., El-Osta, H., 2016).

The highest quality meat is obtained from broilers - hybrid meat young of all types of poultry with specialized cultivation. Broiler white meat contains over $20 \%$ of full proteins, $1-2 \%$ of fat, $92 \%$ of amino acids.

\footnotetext{
*Corresponding author.

E-mail address: shakizada.niyazbekova@gmail.com
} 
Therefore, with a limited feed base, the production of this meat is rapidly developing in the vast majority of countries (Bollman, R.D., Kapitani, M., 2017).

Poultry by-products are widely used. Feather and fluff go to the manufacture of various household supplies, fishing gear, and feed. Raw poultry litter is an organic fertilizer that is valuable in the composition and degree of nutrient absorption by plants. Incubation and slaughter wastes are processed into fodder flour (Summer, D.A., 1982).

At the current level, in the poultry industry, the efficiency and safety of products become vital concepts. At the same time, the requirements for the main link of the poultry production system are changing - agricultural poultry, which should have the main properties - this is a developed immune system and functional adaptation to intensive technologies for the production of eggs and poultry meat; high reproducibility and long productive life; the ability to produce products of high quality and nutritional value; efficient conversion of nutrients and feed energy (Usher, D., 1980).

The achievement of these goals is possible with a comprehensive approach and systematic coordination of geneticists and breeders, animal scientists, and veterinary specialists of a comprehensive profile (Sigarev, M.I., Nurkuzhaev, Zh.M., \& Alshembaeva, L.T., 2020).

In 2018, there were 60 poultry farms in the Republic of Kazakhstan. In the egg direction, Kazakhstan fully provides the domestic market; more than 179 thousand tons of poultry meat was produced.

Today, the Kazakhstan market's demand for poultry meat is about 250-300 thousand tons, of which domestic products occupy only half of the market.

Currently, the poultry industry belongs to one of the most promising sectors of the agro-industrial complex of the Akmola region, which is due to a whole range of factors of both a general economic and specific regional nature. At the same time, the efficiency of individual poultry enterprises, especially those specializing in poultry meat production, remains low, which requires the development of improved models for evaluating their activities and optimizing their functioning.

In this regard, the authors of the article attempt to prove that conducting a production analysis of the company's activities will help to improve the qualitative and quantitative indicators of the products produced and will increase the financial and economic indicators of the enterprise.

The study hypothesizes that it can be proved that the productive activity of the Izhevsk production cooperative satisfies the population's need for poultry products in the city of Nur-Sultan and the Akmola region.

\section{Literature Review}

In the economic literature, various scientific problems of the functioning and development of the poultry production sub-complex of the country and some of its regions are considered, theoretical and methodological approaches to the justification of increasing the economic efficiency of the poultry industry are highlighted. The above aspects of scientific problems were studied in the works of I.A. Bakhtin, L.A. Belova, V.R. Boev, I.N. Buzdalov, E.B.Igumenova, R.A. Grishko, N.V. Denin, V.A. Dobrynin, M.M. Zhigalin, S. Noorani, D.Bhattarai, S.O.Omondi, E.Hirwa.

E.B. Igumenova in her work justifies that industrial poultry farming is one of the few specialized industries of the agro-industrial complex that can produce products in significant volumes and in a short time regardless of the season of the year (Igumenova, E.B., 2012).

In the findings of R.A.Grishko is confirmed that in today's circumstances, new theoretical and practical approaches to the development of this unique industry are needed in order to quickly saturate the market with high-quality dietary foods with minimal production costs (Grishko, R.A., 1995).

D. Bhattarai believes that "Poultry is one of the fastest-growing segments of the agricultural economy, particularly in developing countries. By using different econometric models, this study estimated the production efficiency and effectiveness of poultry farming" (Bhattarai D., 2016).

Emmanuel Hirwa identifies that today, in emerging economies, the poultry subsector has become known as a means of sustaining livelihoods, reducing poverty and malnutrition (Hirwa, E., 2018).

An essential place in the work of scientist S.O. Omondi is given to the economic analysis of small-scale poultry production, where urban local chicken production has a dual role in providing food and income generation. His study argues that the importance of urban agriculture depends on the type of agricultural practice in cities (Omondi, S.O., 2018).

However, there is no comprehensive scientific approach to the study of the formation of market relations, the development of the organizational and economic mechanism of management, the improvement of the management of poultry enterprises, the organization of financial and innovative management in intensive 
poultry farming, as well as the development of a system of measures to increase the efficiency of the development of the poultry industry at the regional level concerning Akmola region. This region remains little studied; therefore, it represents a particular scientific value. Many theoretical and methodological recommendations require clarification, taking into account the region's specific organizational and economic conditions.

\section{Methods}

Statistics from the company's official website, as well as materials provided by the company's management, were used to assess the state of production activities of the Izhevsky production cooperative. For the analysis of the industry, in general, statistical journals, reports, bulletins, articles by scientists involved in these studies. In the process of performing the work, the following research methods were used: - abstractlogical - to substantiate the goal, tasks, working hypothesis and priority areas of poultry development; generalizations of methodological approaches to the assessment of the level of poultry development; - economic and statistical - in the study of the current state and main trends, - graphic - in the graphical presentation of statistical data; - monographic - in the study and synthesis of domestic and foreign experience in poultry development. Microsoft Word, Microsoft Excel applications were used in the processing of statistical material and the design of work.

\section{Results}

Considering the Izhevsky production cooperative, we can distinguish this is a multisectoral agricultural enterprise. It is located in the Republic of Kazakhstan, Akmola region, Arshalinsky district, the village of Izhevsky.

Main areas of activity:

- egg production

- grain production (there is the status of an elite seed and seed-and-crop economy)

- poultry meat production

- dairy husbandry

- horse breeding

- processing of agricultural products.

The Izhevsky production cooperative produces milk, poultry meat, cattle meat, horse meat, sausages, smoked and dairy products, egg products, flour, pasta, bakery products, and other products. In total, more than 70 names. These products are delivered daily to the outlets of Nur-Sultan, as well as other cities of Kazakhstan and Russia. The total annual production of agricultural products is 180 million pieces of chicken eggs, 900 tons of milk, 530 tons of poultry meat, 27,000 tons of cereals. The land of the farm is 21,462 hectares, including 15,296 hectares of arable land [5]. We evaluated the production activities of the Izhevsky poultry farm, which is presented in Table 1 .

Table 1 Analysis of the poultry farm "Izhevsky"

\begin{tabular}{|c|c|c|c|c|c|c|c|}
\hline \multirow[t]{2}{*}{$\mathrm{No}$} & \multirow{2}{*}{ Indicators } & \multirow{2}{*}{$\begin{array}{l}\text { Unit of } \\
\text { measure }\end{array}$} & \multicolumn{3}{|c|}{ Years } & \multicolumn{2}{|c|}{$\begin{array}{l}\text { Deviations } \\
2019 / 2017\end{array}$} \\
\hline & & & 2017 & 2018 & 2019 &,+- & $\%$ \\
\hline 1 & Number of poultry houses of all chickens & units & 26 & 32 & 32 & 6 & 23,08 \\
\hline 2 & Number of poultry houses of all laying hens & units & 22 & 26 & 26 & +4 & 18,19 \\
\hline 3 & Number of poultry houses of all young chickens & units & 4 & 6 & 6 & +2 & 50 \\
\hline 4 & Number of laying hens in each poultry house & pieces & 31701 & 52576 & 44571 & +12870 & 40,6 \\
\hline 5 & In fact, the number of all laying chickens & pieces & 824226 & 977827 & 1035092 & 210866 & 25,59 \\
\hline 6 & Number of all young chickens & pieces & 370200 & 495955 & 427511 & 57311 & 15,49 \\
\hline 7 & Number of young chickens in each poultry house & pieces & 92550 & 82659 & 71252 & -21298 & $-23,02$ \\
\hline
\end{tabular}

Based on Table 1 it can be seen that poultry houses grew by 6 units or $23.08 \%$ and in 2018 there were 32 units of the Izhevsky production cooperative, while poultry houses for young chickens were opened, so in 2017 - 2 units, 2018/2019 they amounted to 4 units.

When evaluating the production activities of the Izhevsky production cooperative, we studied the production of laying chickens and young chickens, which are considered in Table 2. 
Table 2 Analysis of the number of chickens in pieces and specific gravity of the total number of chickens at the Izhevsky poultry farm, pieces

\begin{tabular}{|c|c|c|c|c|c|c|c|c|c|}
\hline \multirow{3}{*}{ № } & \multirow{3}{*}{ Indicators } & \multicolumn{6}{|c|}{ Years } & \multicolumn{2}{|c|}{$\begin{array}{l}\text { Deviations } \\
2019 / 2017\end{array}$} \\
\hline & & \multicolumn{2}{|c|}{2017} & \multicolumn{2}{|l|}{2018} & \multicolumn{2}{|l|}{2019} & \multirow{2}{*}{,+-} & \multirow{2}{*}{$\%$} \\
\hline & & units & $\%$ & units & $\%$ & units & $\%$ & & \\
\hline 1 & Number of total bearing chickens & 824226 & 69 & 977827 & 67 & 1035092 & 71 & 210866 & 25,6 \\
\hline 2 & The number of all young chickens, & 370200 & 31 & 495955 & 33 & 427511 & 29 & 57311 & 15,5 \\
\hline 3 & Total chickens at the poultry farm & 1194426 & 100 & 1473782 & 100 & 1462603 & 100 & +268177 & $+22,46$ \\
\hline
\end{tabular}

Having estimated the number of chickens at the Izhevsky poultry farm, it might be seen that the number of chickens from 2017 to 2019 has increased, see table 2:

- the number of chickens per $22.46 \%$ or 268,177 pieces in a poultry farm and 2019 year - 1,462603 pieces;

- the number of laying hens by $25.6 \%$ or by 210,866 pieces and in 2019 - 1,035092 pieces is more than in 2018 than by 52,265 pieces or $5.9 \%$;

- numbers of young chickens - $15.5 \%$ and amounted to in 2019 - 427,511 units.

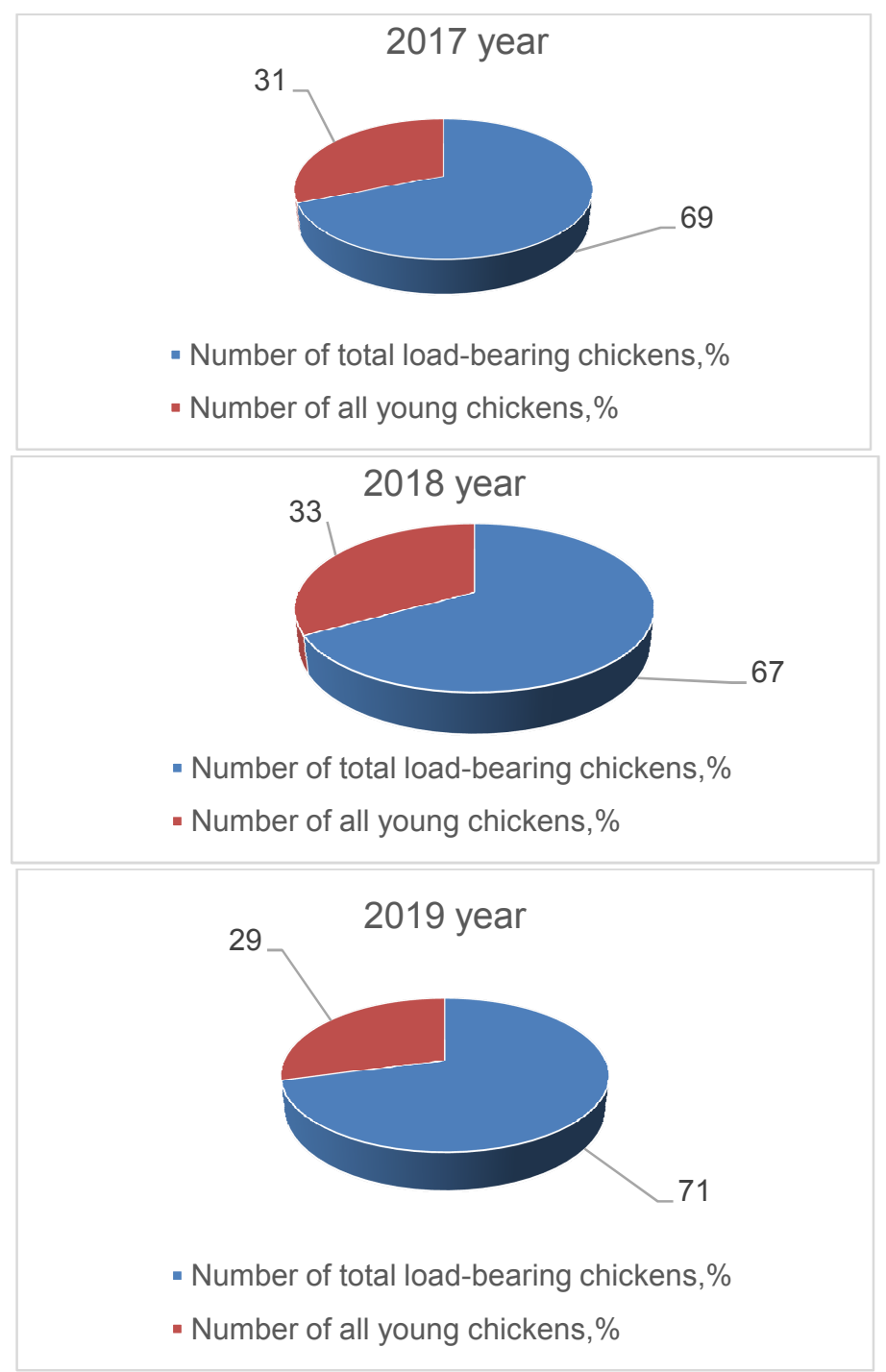

Figure 1 - 3 - Specific weights of bearing hens and young hens in the total structure of the number of all hens of the Izhevsky production cooperative for individual years 2017, 2018, 2019.

Note - compiled by the authors on the basis of the source (http://ijevski.kz). 
Based on Figures 1-3of specific weights of laying hens and young hens in the whole structure of the number of all hens of the Izhevsky production cooperative according to individual 2017, 2018, 2019 and Tables 2 , it can be seen that the specific gravity of bearing hens increased over three years by $2 \%$ and amounted to $71 \%$. The proportion of young chickens in the total number of chickens at the poultry farm decreased by $2 \%$ and is $29 \%$ in 2018 , and this indicates an increase in the number of laying hens compared to young people by $2 \%$.

Table 3 Analysis of the average number of laying hens and young hens in one poultry house of the Izhevsky production cooperative, pieces.

\begin{tabular}{|l|l|c|c|c|c|c|}
\hline \multirow{2}{*}{ № } & Indicators & \multicolumn{3}{c|}{ Years } & \multicolumn{2}{c|}{$\begin{array}{c}\text { Deviations } \\
2019 / 2017\end{array}$} \\
\cline { 3 - 7 } & & 2017 & 2018 & 2019 &,+- & $\%$ \\
\hline 1 & Average number of laying hens in each poultry house & 37465 & 37609 & 39811 & +2346 & 6,27 \\
\hline 2 & Average number of young chickens in each poultry house & 92550 & 82659 & 71252 & -21298 & $-23,02$ \\
\hline
\end{tabular}

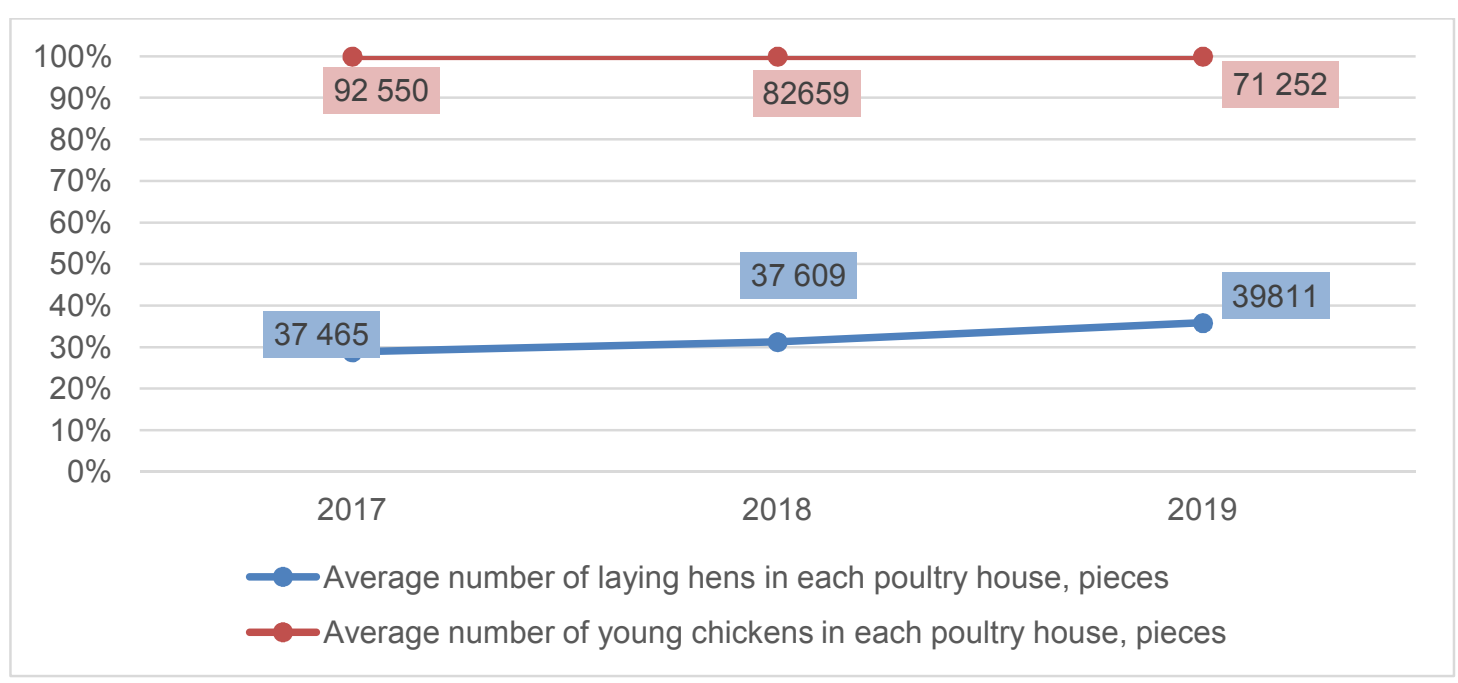

Figure 4 - The average number of laying hens and young hens in one poultry house of the Izhevsky production cooperative, pieces.

Note - compiled by the authors on the basis of the source (http://ijevski.kz).

Table 3 and figure 4 show that the average number of laying hens in each poultry house is growing from year to year and their growth for the period under review was $6.27 \%$ or +2346 pieces, while in 2019 39,811 pieces, which is $5.86 \%$ higher compared to the previous year 2018 .

The average number of young chickens in each poultry house was decreased over the period (20172019) by $23.02 \%$ or 21,298 units and amounted to 71,252 units in 2019.

Table 4 Egg production at the Izhevsky poultry farm.

\begin{tabular}{|c|c|c|c|c|c|c|c|c|c|}
\hline \multirow{3}{*}{ № } & \multirow{3}{*}{ Indicators } & \multirow{3}{*}{$\begin{array}{l}\text { Unit of } \\
\text { measure }\end{array}$} & \multirow{2}{*}{\multicolumn{3}{|c|}{ Years }} & \multicolumn{4}{|c|}{ Deviations } \\
\hline & & & & & & \multicolumn{2}{|c|}{ 2019/2017 } & \multicolumn{2}{|c|}{$2019 / 2018$} \\
\hline & & & 2017 & 2018 & 2019 &,+- & $\%$ &,+- & $\%$ \\
\hline 1 & $\begin{array}{l}\text { Egg production in poultry } \\
\text { houses for the year }\end{array}$ & $\begin{array}{c}\text { thousand } \\
\text { units }\end{array}$ & 280035 & 305705 & 308457 & 28422 & 10,15 & 2752 & 1 \\
\hline 2 & $\begin{array}{l}\text { Egg production on average } \\
\text { for each poultry house }\end{array}$ & $\begin{array}{c}\text { thousand } \\
\text { units }\end{array}$ & 12728,87 & 11757,89 & 11863,73 & $\begin{array}{c}- \\
865,14\end{array}$ & $-6,8$ & 105,84 & 1 \\
\hline 3 & $\begin{array}{l}\text { Production of eggs by } 1 \\
\text { chicken carrier per year }\end{array}$ & pieces & 340 & 313 & 298 & -42 & $-12,36$ & -15 & $-4,8$ \\
\hline 4 & $\begin{array}{l}\text { Production of eggs } 1 \\
\text { chicken carrier per month }\end{array}$ & pieces & 28 & 26 & 25 & -3 & $-10,72$ & -1 & 4 \\
\hline 5 & $\begin{array}{l}\text { Production of eggs } 1 \\
\text { chicken carrier per week }\end{array}$ & pieces & 7 & $7-6$ & 7 & -1 & $-14,29$ & - & - \\
\hline
\end{tabular}


Analyzing the production of eggs at the Izhevsky poultry farm shows that, in general, the factory experienced an increase in egg production from 2017 to 2019 by $10.1 \%$ and amounted to 30857 thousand units in 2018.

If we consider egg production on average for each poultry house, then there was a decrease of $-6.8 \%$ over three years, but this decrease is due to an increase in the number of poultry hens from 22 units to 26 units, i.e., by four units in $2018-2019$, which made it possible to distribute poultry hens to additional poultry houses

Table 5 Production of meat chicken products in the Izhevsky production cooperative, tons

\begin{tabular}{|c|c|c|c|c|c|c|c|c|}
\hline \multirow{3}{*}{ № } & \multirow{3}{*}{ Indicators } & \multirow{2}{*}{\multicolumn{3}{|c|}{ Years }} & \multicolumn{4}{|c|}{ Deviations } \\
\hline & & & & & \multicolumn{2}{|c|}{$2019 / 2018$} & \multicolumn{2}{|c|}{$2019 / 2017$} \\
\hline & & 2017 & 2018 & 2019 &,+- & $\%$ &,+- & $\%$ \\
\hline 1 & Chicken meat production for the year & 798 & 801 & 956 & +155 & $+19,35$ & +158 & $+20,0$ \\
\hline 2 & $\begin{array}{l}\text { Chicken meat production per poultry } \\
\text { house per year }\end{array}$ & 36,28 & 30,81 & 36,77 & $+0,498$ & 1,35 & $+0,49$ & 1,35 \\
\hline 3 & $\begin{array}{l}\text { Total monthly production of chicken } \\
\text { meat }\end{array}$ & 3,08 & 2,57 & 3,07 & 0,5 & 19,46 & 0,02 & 0,33 \\
\hline 4 & $\begin{array}{l}\text { Average daily production of chicken } \\
\text { meat - total }\end{array}$ & 0,16 & 0,13 & 0,16 & 0,03 & 23,08 & - & - \\
\hline
\end{tabular}

By studying the production of chicken meat in the Izhevsky production cooperative, actual data can be reviewed, which show that the production of these products for $2017-2019$ increased by $20 \%$ or +158 tons and in 2019 - 956 tons. If we make comparisons with the previous year 2019/2018, it is clear that volume growth amounted to 155 tons, which is $19.35 \%$ higher.

All output indicators, according to Table 5 and Figure 5 show dynamic growth, as follows:

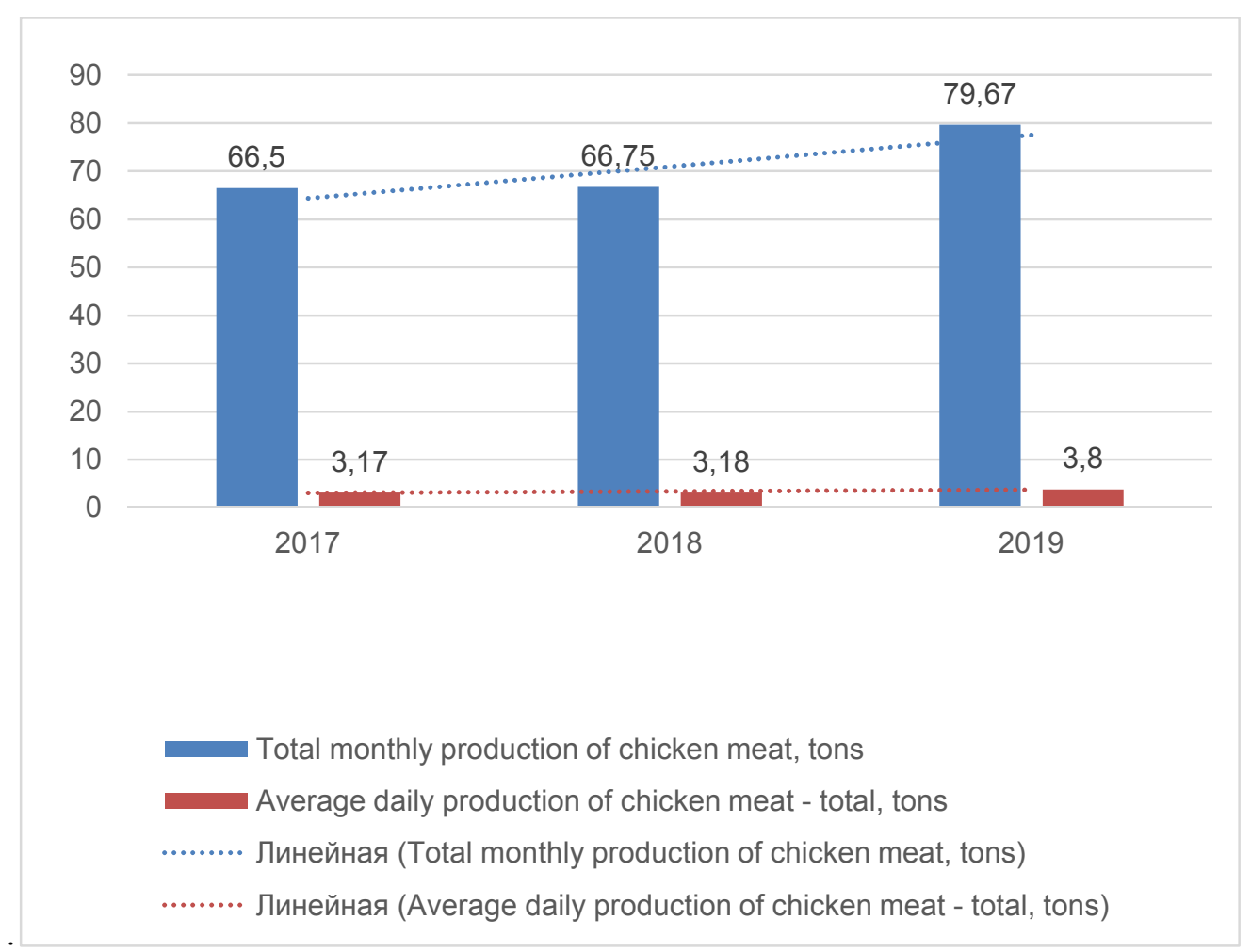

Figure 5 - Average monthly and average daily production of chicken meat in general at the Izhevsky poultry farm. Note - compiled by the authors on the basis of the source (http://ijevski.kz). 
- the production of chicken meat for each poultry house increased by $+1.35 \%$ in three years, in $2019 / 2018$ years an increase of +0.49 tons, which amounted to 36.77 tons per year in 2019;

- the average monthly production of chicken meat for the total poultry farm in 2017 amounted to 3.08 tons, in 2018 - 2.57 tons, in 2019 - 3.07 tons, i.e., there was an increase after the installation on $19.46 \%$.

- the average daily production of chicken meat also increased by $23.08 \%$ compared to 2018 and amounted to 0.16 tons/day in 2019.

Thus, it can be concluded that all production activities are growing dynamically, and the Izhevsky production cooperative is characterized as an enterprise with sustainable development

\section{Discussions}

From 2012 to 2019, the amount of poultry meat per capita is six times higher than in the domestic market. A significant share of the population in the meat market will pose a significant threat to food security, exacerbated by a massive dependence on megacities (Alibaeva, Zh.N., \& Traisov, B.B., 2015).

Annually increase the production of commercial poultry enterprises such as the Izhevsky production cooperative, Sarybulak Company LLP, Kazakhstan Bushes LLP, Shymkent Kus LLP, KazherKus LLP, Ural Poultry Farm LLP. Nevertheless, there is a need for a low level of technological equipment, underutilization of production capacities of enterprises, as well as a high cost of production. Broiler production capacity in the republic as a whole is used by $60-70 \%$. According to the standards for the month from egg chickens, you can get from 17 to 26 eggs per week - 4-6 pcs. Meat-egg chickens carry less than 160-180 days a year. Stable - once every two days. A month, universal chicken is quite good: 13-15 pcs (Kimbi, A. \& Lee, M., 1996). A week - 3-4 pcs. Egg chickens are record holders in egg production. Small and very mobile, they are selfless workers. Their productivity is in the range of 200-240 eggs. Egg hybrids are higher: 280-320 pcs (Knoeber, C.R., \& Thurman, W.N., 1995). In summer, such chickens are carried often, almost daily. In winter - less often. On average, it turns out from one egg per day to one per two days, depending on the year. At the same time, for a month from egg chickens, you can get from 17 to 26 eggs per week - 4-6 pcs. Meat-egg chickens carry less than 160-180 days a year. Stable - once every two days. A month, universal chicken is quite good: 13-15 pcs., And a week - 3-4 pcs (Shevchenko, A.A., Bojchenko, A.A., \& Myasoedov, A.Yu., 2020).

Meat carries the worst, but when they were brought out, there were other priorities. The productivity of one such chicken is in the range of 120-160 per year. The eggs of heavyweights are more extensive than those carried by the laying chicken. On average, it turns out that one egg appears once every three days. You can expect 10-13 units per month, 2-3 units per week (Devine, P. J., Jones, R.M., Lee, N., \& Tyson, W.J., 1976).

"The monitoring of poultry production prices by the Poultry Union shows that, despite rising feed prices and their component, seasonality, on currency jumps - in 2016 - 340 tenge, in 2017-2018 - 370-380 tenge, in 2019 - 390-410 tenge, untimely and incomplete receipt of subsidies and other production problems, poultry farms have been keeping and not raising prices in good faith, since the beginning of the year, according to some reports, there was an increase in prices for poultry meat by $4 \%$. Thus, the production of a unit of livestock fodder production makes up the most significant part. Their share in poultry production cost, depending on its type, is about 70\% (Mothae, N., 1999).

The Izhevsky production cooperative is one of the leading producers of milk, poultry meat, cattle meat, horse meat, sausages, smoked and dairy products, egg products, flour, pasta, bakery products, and other products in Akmola region. In total, more than 70 names. These products are delivered daily to retail outlets in Astana and other cities of Kazakhstan and Russia (Svoya ferma, 2020). The total annual production of agricultural products is 180 million pieces of chicken eggs, 900 tons of milk, 530 tons of poultry meat, 27 000 tons of cereals. The land of the farm is 21462 hectares, including 15296 hectares of arable land.

Production activity is steadily growing for the period from 2017 to 2019 as follows:

- the number of poultry houses increased from 26 units to 32 units;

- all in the poultry farm the number of chickens by $22.46 \%$ or 268177 pieces and in $2019-1462603$ pieces;

- the growth of chicken meat from 2019/2018 volumes is 19.35\% higher;

- egg production increased in three years by 28422 thousand units or $10.15 \%$.

The scientific novelty of the study consists in the fact that based on studying the scientific and methodological aspects of the problem under study, the necessary capacities for the production and production of 
poultry products of the production cooperative are determined to determine the population's demand for these types of products and meet the need for them.

The practical significance of the study is that the main provisions on the assessment of activities can also be used for practical application by many poultry enterprises in Kazakhstan and will contribute to further improving the efficiency of the industry.

\section{Conclusions}

In this study, we analyzed the modern development of poultry farming in Kazakhstan, including the Izhevsky production cooperative of Akmola region (Serikpaev, D., 2020). The Izhevsky production cooperative carries out various activities and produces milk, poultry meat, cattle meat, horse meat, sausages, smoked and dairy products, egg products, flour, pasta, and bakery, and other products. In total, more than 70 names. However, the main activity is the production of eggs and chicken meat. For this, the Izhevsky production cooperative has 32 poultry houses on its balance sheet, in which in 2019, the number of laying hens is 1035 092 pieces, the number of all young hens - 427511 pieces. The Izhevsky production cooperative produces 308457 thousand eggs during the period under review, and 956 tons of chicken meat production per year.

All the production activities of the Izhevsk PC show that it is growing dynamically and is characterized as an enterprise with sustainable production development, which proves the hypothesis set in this study. This is a factor that satisfies the population's need for poultry products in the city of Nur-Sultan and Akmola region, which characterizes the indicator of the physical accessibility of these products to ensure food security in the region (Serikov, D., 2019).The main conclusions drawn from the calculations can be used in the development of strategic plans for the development of poultry farming in the region.

It should be noted that the development of poultry farming in general is one of the most important industries that ensure the sustainable development of agriculture in the country and the region.

We note that the article was prepared as part of the research work of the state order under budget program 217 on the priority "Rational use of natural resources, including water resources, geology, processing, new materials and technologies, safe products and structures "according to the scientific and technical program" Reducing the technological impact on water resources using water recycling technology "of the section" Economic efficiency from reducing the technological impact on water resources using water recycling technology in the Izhevsky poultry farm".

\section{References}

Ahearn, M., \& El-Osta, H. (2016). The role Of-Farm Employment: Permanent or Transitional State?. American Journal of Agricultural Economics, 82(1), 38-46.

Alibaeva, Zh.N., \& Traisov, B.B. (2015). Razvitie pticevodstva v kazahstane [Poultry development in Kazakhstan]. Zhurnal Izvestiya Orenburgskogo gosudarstvennogo agrarnogo universiteta, Ekonomicheskie nauki. Retrieved from https://cyberleninka.ru/article/n/razvitie-ptitsevodstva-v-kazahstane [in Russian].

Bhattarai, D. (2006). An Economic Analysis of Poultry Egg Production in Nepal. Pakistan Journal of Nutrition, 15 (8), 715-716.

Bollman, R.D., \& Kapitani, M. (2017). Entry and Exist Function For Farmers. American Journal of Agricultural Economics, 82(1), 39-42.

Gosudarstvennaya programma razvitiya agropromyshlennogo kompleksa Respubliki Kazahstan na 2017-2021 gody [State programme for the development of the agro-industrial complex of the Republic of Kazakhstan for 20172021]. Fao.org. Retrieved from http://www.fao.org/fileadmin/user_upload/reu/europe/documents/compnew/Kaz PDF5.pdf [in Russian].

Grishko, R.A., (1995). Organizacionno-ekonomicheskie voprosy razvitiya pticevodstva $\mathrm{v}$ usloviyah perekhoda $\mathrm{k}$ rynochnym otnosheniyam [Organizational and economic issues of the development of poultry farming in the context of the transition to market relations]. An abstract of the dissertation of the candidate of economic sciences, Higher School of Management of the Agricultural Complex and Agribusiness, p. 3.

Devine, P. J., Jones, R.M., Lee, N., \& Tyson, W.J. (1976). An Introduction to Industrial Economics, 2nd ed. London, George Allen and Unwin Ltd, 45.

Hirwa, E. (2018). An Economic Analysis Of Poultry Production Efficiency And Marketing In Rwanda. Poultry Production Efficiency And Marketing In Rwanda, University of Nairobi.

Igumenova, E.B. (2012). Increasing the efficiency of industrial poultry production in the market [Povyshenie effektivnosti promyshlennogo pticevodstva v usloviyah rynka]. Dostizheniya nauki i tekhniki APK, 8, 71-85.

Kimbi, A. \& Lee, M. (1996). Off-Farm Work Decisions of farm couples: Estimating Structural Simultaneous Equations with ordered categories Dependent Variables. American Journal of Agricultural Economics, 78 (1), 687-698.

Knoeber, C.R., \& Thurman, W.N. (1995). Don't count your chickens ...Risk and Risk shifting in the Broilers Industry. American Journal of Agriculture Economics. 7(2), 486-496. 
Mothae, N. (1999). Poultry farming: study on profitability and its factors. Economics Department project study, National University Lesotho.

Oficial'nyj sajt PK "Izhevskij" [The official website of the Izhevsky production cooperative]. Retrieved from http://ijevski.kz/

Omondi, S.O. (2018). Economic analysis of small-scale poultry production in Kenyan medium-sized cities of Kisumu and Thika. Conference of International Association of Agricultural Economists, July 28-August 2, 2018, Vancouver, British Columbia.

Programma po razvitiyu agropromyshlennogo kompleksa v Respublike Kazahstan na 2013-2020 gody «Agrobiznes2020» [Agro-industrial complex development program in the Republic of Kazakhstan for 2013-2020 "Agribusiness2020]. Business, gov.kz. Retrieved from https://business.gov.kz/ru/business-support-programs/detail.php?ID=50944 [in Russian].

Serikov, D. (2019). Proizvodstvo ptich'ego myasa v Kazahstane ponemnogu rastet [Poultry meat production in Kazakhstan grows slightly]. inbusiness.kz. Retrieved from https://inbusiness.kz/ru/news/proizvodstvo-ptichego-myasa-vkazahstane-ponemnogu-rastet [in Russian].

Serikpaev, D. Hudshee vperedi: prognoz po ekonomike Kazahstana na 2020 god [Worst ahead: forecast for Kazakh$\begin{array}{lllll}\text { stan's } & \text { economy } & \text { for } & \text { 2020]. } & \text { forbes.kz. }\end{array}$ https://forbes.kz//finances/finance/neft_po_32_dollar_po_424_tenge_prognoz_po_ekonomike_kazahstana_na_2020_god/[in Russian].

Shevchenko, A.A.A., Bojchenk̄o, A.A., \& Myasoedov, A.Yu. Povyshenie effektivnosti ochistki stochnyh vod OAO "Pticefabrika Kaluzhskaya" [Improvement of efficiency of waste water treatment of Poultry Farm Kaluga OJSC]. eprints.kname.edu.ua. Retrieved from http://eprints.kname.edu.ua/38187/1/102-104 [in Russian].

Sigarev, M.I., Nurkuzhaev, Zh.M., \& Alshembaeva, L.T. (2020). Pticevodstvo Kazahstana: sostoyanie i problemy razvitiya, 2020 [A Poultry farming of Kazakhstan: state and development problems,]. abkaz.kz. Retrieved from http://abkaz.kz/pticevodstvo-kazaxstana-sostoyanie-i-problemy-razvitiya/ [in Russian].

Summer, D.A. (1982). The Off-Farm labour supply of Farmers. American Journal of Agricultural Economics, 64(1), 499-509.

Svoya ferma. (2020). Skol'ko vsego yaic v den' neset kurica: kak mozhno povysit' yajcenoskost' [How many eggs a day a chicken carries: how can you increase egg production]. FermaGid.ru. Retrieved from http://fermagid.ru/kury/438skolko-yaic-v-den-neset-kurica.html\#nachalo [in Russian].

Usher, D. (1980). The Measurement of Economic Growth. Working Papers 145, Queen's University, Department of Economics. Oxford.

\section{К.С. Мейрамкулова, М.О. Рыспекова, Ш.У. Ниязбекова, А.А. Дуйсенбекова \\ Ақмола облысы «Ижевский» өндірістік кооперативінің өндірістік қызметінін ағымдағы жағдайын талдау}

\section{Aндаmna:}

Maқ̧саты: Құс шаруашылығы - бұл Қазақстанның агроөнеркәсіптік кешенінің заманауи жүйесінде қарқынды дамып келе жатқан салалардың бірі. Бүгінгі күні жоғары сапалы құс өнімдерін тиімді өндіруді ынталандыру өте маңызды. Мақалада Ақмола облысындағы «Ижевский» өндірістік кооперативінің өндірістік қызметіне экономикалық шолу жасалған, осы кәсіпорындағы өндірістің қазіргі жағдайы сапалы және сандық түрде қарастырылған.

Әдісі: Жұмысты орындау процесінде келесі зерттеу әдістері қолданылды: жүйелік, логикалық және салыстырмалы талдау әдістері, статистикалық әдістер. Зерттеудің ақпараттық-эмпирикалық базасы Қазақстан Республикасы Ұлттық экономика министрлігі Статистика комитетінің, Ақмола облысының ауыл шаруашылығы департаментінің деректері, «Ижевский» өндірістік кооперативінің статистикалық есептілігі, сонымен қатар анықтамалық материалдар, ғылыми-әдістемелік ұсыныстар, экономикалық мерзімді басылымдар, Интернеттің ақпараттық әлеуеті болды.

Kорытынды: Ақмола облысындағы құс шаруашылығының қазіргі жағдайына қысқаша шолу жасалды, «Ижевский» өндірістік кооперативінің өндірістік қызметінің негізгі экономикалық көрсеткіштері талданды. Авторлар жасаған ұсыныстарды ауылшаруашылық тауар өндірушілері, аудандық және облыстық ауылшаруашылық бөлімдері пайдалана алатындығын ескеру қажет.

Тұжырымдама: Есептеулер нәтижесінде тұжырымдалған негізгі тұжырымдар аймақтағы құс шаруашылығын дамытудың стратегиялық жоспарларын құруда қолданылуы мүмкін.

Kiлm сөздер: ауыл шаруашылығы, құс шаруашылығы, мал шаруашылығы, тауықтар салу, құс үйі, бордақылау, құрама жем, құс өнімділігі. 


\section{К.С. Мейрамкулова, М.О. Рыспекова, Ш.У. Ниязбекова, А.А. Дуйсенбекова \\ Анализ современного состояния производственной деятельности производственного кооператива «Ижевский» Акмолинской области}

\section{Аннотация}

Цель: Одной из наиболее динамично развивающихся отраслей в современной системе агропромышленного комплекса Казахстана является птицеводство. На сегодняшний день крайне важны выпуск высококачественной продукции птицеводства и развитие эффективного производства. В статье произведен экономический обзор производственной деятельности производственного кооператива «Ижевский» Акмолинской области, качественно и количественно рассмотрено современное состояние выпуска продукции на данном предприятии.

Memoдbl: В процессе выполнения работы использовались следующие методы исследования: системный, логический и сравнительный анализ и статистические методы. Информационно-эмпирической базой исследования послужили данные Комитета по статистике Министерства национальной экономики Республики Казахстан, Управления сельского хозяйства Акмолинской области, статистической отчетности Производственного кооператива «Ижевский», справочно-нормативные материалы, научно-методические рекомендации, экономические периодические издания, а также информационный потенциал сети Интернет.

Pезультаты: Проведен краткий обзор современного состояния птицеводческой отрасли Акмолинской области, проанализированы основные экономические показатели производственной деятельности Производственного кооператива «Ижевский». Следует отметить, что предложения, сделанные авторами, могут быть использованы сельскохозяйственными товаропроизводителями, районными и областными управлениями сельского хозяйства.

Bblвoдbl: Основные выводы, сформулированные в результате расчетов, могут быть использованы при разработке стратегических планов развития птицеводства в регионе.

Ключевые слова: сельское хозяйство, птицеводство, животноводство, куры-несушки, птичник, кормление, комбикорма, продуктивность птицы.

\section{References}

Ahearn, M., El-Osta, H. The role Of-Farm Employment: Permanent or Transitional State? [Текст] / M. Ahearn, H. ElOsta // American Journal of Agricultural Economics. — 2016 — № 82(1). - P.38-46.

Bhattarai, D. An Economic Analysis of Poultry Egg Production in Nepal [Текст] / D. Bhattarai // Pakistan Journal of Nutrition. - 2006. - № 15 (8). - p. 715-716.

Bollman, R.D., Kapitani, M. Entry and Exist Function For Farmers [Текст] / R.D. Bollman, M. Kapitani // American Journal of Agricultural Economics. — 2017. — № 82(1). - P. 39-42.

Devine, P. J., Jones, R.M., Lee, N., Tyson, W.J. An Introduction to Industrial Economics [Текст] / P. J. Devine, R.M. Jones, N. Lee, W.J. Tyson // 2nd ed. London, George Allen and Unwin Ltd. - 1976. — P. 45.

Hirwa, E. An Economic Analysis Of Poultry Production Efficiency And Marketing In Rwanda [Tекст] / E.Hirwa // Poultry Production Efficiency And Marketing In Rwanda. — University of Nairobi. — 2018.

Kimbi, A. Lee, M. Off- Farm Work Decisions of farm couples: Estimating Structural Simultaneous Equations with ordered categories Dependent Variables [Текст] / A. Kimbi, M. Lee //American Journal of Agricultural Economics. — 1996. — № 78 (1). — P. 687-698.

Knoeber, C.R., Thurman, W.N. Don't count your chickens...Risk and Risk shifting in the Broilers Industry [Текст] / C.R. Knoeber, W.N. Thurman // American Journal of Agriculture Economics. — 1995. — № 7(2). — P. 486-496.

Mothae, N. Poultry farming: study on profitability and its factors [Текст] / N. Mothae // Economics Department project study. - National University Lesotho. - 1999.

Omondi, S.O. Economic analysis of small-scale poultry production in Kenyan medium-sized cities of Kisumu and Thika [Текст] / S.O.Omondi // Conference of International Association of Agricultural Economists. - Vancouver, British Columbia. - July 28-August 2, 2018.

Summer, D.A. The Off-Farm labour supply of Farmers [Текст] / D.A. Summer // American Journal of Agricultural Economics - 1982. - № 64(1). - P. 499-509.

Usher, D. The Measurement of Economic Growth [Текст]. / D. Usher // Working Papers 145, Queen's University, Department of Economics. Oxford. - 1980.

Алибаев Ж.Н. Развитие птицеводства в Казахстане [Текст] / Ж.Н. Алибаев, Б.Б. Траисов // Изв. Оренбург. гос. аграр. ун-та. — 2014. - (Режим доступа: https://cyberleninka.ru/article/n/razvitie-ptitsevodstva-v-kazahstane)

Государственная программа развития агропромышленного комплекса Республики Казахстан на 2017-2021 годы [Текст]. - (Режим доступа: http://www.fao.org/fileadmin/user_upload/reu/europe/documents/compnew/Kaz_ PDF5.pdf)

Гришко Р.А. Организационно-экономические вопросы развития птицеводства в условиях перехода к рыночным отношениям: автореф. дис. ... канд. экон. наук: 08.00.05 / Р.А. Гришко // Высш. шк. управления АПК и агробизнеса. - М., 1995. - С. 3. 
Игуменова Е.Б. Повышение эффективности промышленного птицеводства в условиях рынка / Е.Б. Игуменова // Достижения науки и техники АПК. - 2012. — № 8. - С.71-85.

Официальный сайт ПК «Ижевский». — 2020. — (Режим доступа: http://ijevski.kz/)

Программа по развитию агропромышленного комплекса в Республике Казахстан на 2013-2020 годы «Агробизнес - 2020» [Текст]. - (Режим доступа: https://business.gov.kz/ru/business-supportprograms/detail.php? ID=50944)

Сериков Д. Производство птичьего мяса в Казахстане понемногу растет / Д.Сериков // — 2019. - (Режим доступа: https://inbusiness.kz/ru/news/proizvodstvo-ptichego-myasa-v-kazahstane-ponemnogu-rastet)

Серикпаев Д. Худшее впереди: прогноз по экономике Казахстана на 2020 год [Текст] / Д.Серикпаев. — (Режим доступа: _prognoz_po_ekonomike_kazahstana_na_2020_god/)

Сигарев М.И. Птицеводство Казахстана: состояние и проблемы развития [Текст] / М.И. Сигарев, Ж.М. Нуркужаев Л.Т. Алшембаева // — 2020. — (Режим доступа: http://abkaz.kz/pticevodstvo-kazaxstanasostoyanie-i-problemy-razvitiya/)

Сколько всего яиц в день несет курица: как можно повысить яйценоскость // Своя ферма, FermaGid.ru. — 2020. — (Режим доступа: http://fermagid.ru/kury/438-skolko-yaic-v-den-neset-kurica.html\#nachalo)

Шевченко А.А. Повышение эффективности очистки сточных вод ОАО «Птицефабрика Калужская» / А.А. Шевченко, А.А. Бойченко, А.Ю. Мясоедов. - (Режим доступа: eprints.kname.edu.ua/38187/1/102-104) 